ECOLOGICAL SOLIDARITIES 


\section{WORLD CHRISTIANITY}

Dale T. Irvin and Peter Phan, Series Editors

ADVISORY BOARD:

Akintunde E. Akinade

Adrian Hermann

Leo D. Lefebure

Elaine Padilla

Yolanda Pierce

Moving beyond descriptions of European-derived norms that have existed for hundreds of years, books in the World Christianity series reflect an understanding of global Christianity that embodies the wide diversity of its identity and expression. The series seeks to expand the scholarly field of world Christianity by interrogating boundary lines in church history, mission studies, ecumenical dialogue, and inter-religious dialogue among Christians and non-Christians across geographic, geopolitical, and confessional divides. Beyond a mere history of missions to the world, books in the series examine local Christianity, how Christianity has been acculturated, and how its expression interacts with the world at large. Issues under investigation include how Christianity has been received and transformed in various countries; how migration has changed the nature and practice of Christianity and the new forms of the faith that result; and how seminary and theological education responds to the challenges of world Christianity. 


\section{ECOLOGICAL SOLIDARITIES}

Mobilizing Faith and Justice for an Entangled World

Edited by Krista E. Hughes, Dhawn B. Martin, and Elaine Padilla

The Pennsylvania State University Press University Park, Pennsylvania 
"How We Become," by Crystal Tennille Irby, is used with kind permission by the artist.

"What If?" by Sapient Soul, is used with kind permission by the artist. A recording of Sapient Soul performing the poem can be found at https:// sapientsoul.bandcamp.com/track/what-if.

Library of Congress Cataloging-in-Publication Data

Names: Hughes, Krista E. (Krista Elizabeth), 1971- editor. | Martin, Dhawn, 1970- editor. | Padilla, Elaine, editor.

Title: Ecological solidarities : mobilizing faith and justice for an entangled world / edited by Krista E. Hughes, Dhawn Martin, and Elaine Padilla.

Other titles: World Christianity (University Park, Pa.)

Description: University Park, Pennsylvania : The Pennsylvania State University Press, [2019] | Series: World Christianity | Includes bibliographical references and index.

Summary: "Employs academic, activist, and artistic perspectives to explore ecologies of interdependence as a frame for religious, theological, and philosophical analysis and practice" - Provided by publisher.

Identifiers: LCCN 2019025523 | ISBN 9780271084626 (cloth)

Subjects: LCSH: Ecotheology. | Ecology—Religious aspects-Christianity. | Human ecology—Religious aspects—Christianity. | Climatic changes-Religious aspects-Christianity.

Classification: LCC BT695.5.E26 2019 | DDC 261.8/8-dc23

LC record available at https://lccn.loc.gov/2019025523

Copyright (C) 2019 The Pennsylvania State University

All rights reserved

Printed in the United States of America

Published by The Pennsylvania State University Press,

University Park, PA 16802-1003

The Pennsylvania State University Press is a member of the Association of University Presses.

It is the policy of The Pennsylvania State University Press to use acid-free paper. Publications on uncoated stock satisfy the minimum requirements of American National Standard for Information SciencesPermanence of Paper for Printed Library Material, ANSI Z39.48-1992. 